\title{
PERAN KELOMPOK TANI CITA IMBAYA TERHADAP PRODUKTIVITAS CABAI DI DESA RAANAN BARU KECAMATAN MOTOLING BARAT KABUPATEN MINAHASA SELATAN
}

\section{THE ROLE OF FARM GROUP CITA IMBAYA ON CHILI PRODUCTIVITY IN RAANAN BARU VILLAGE WEST MOTOLING DISTRICT SOUTH MINAHASA REGENCY}

\author{
Vickv M.E Karundeng $^{(1)}$, Tommy F. Lolowang ${ }^{(2)}$, Ellen G. Tangkere ${ }^{(2)}$
}

1) Mahasiswa Program Studi Agri-Sosioekonomi, Fakultas Pertanian, Universitas Sam Ratulangi, Manado

2) Dosen Program Studi Agribisnis, Fakultas Pertanian, Universitas Sam Ratulangi, Manado

*Penulis untuk korespondensi: tommyferdy@gmail.com

\begin{tabular}{ll}
\hline Naskah diterima melalui e-mail jurnal ilmiah agrisosioekonomi@unsrat.ac.id & : Selasa, 16 Februari 2021 \\
Disetujui diterbitkan & : Jumat, 28 Mei 2021 \\
\hline
\end{tabular}

\begin{abstract}
This research objective is to determine internal and external factors related to the productivity of chili farming and to find out the role of farmer groups in chili productivity in Raanan Baru village. This research was conducted from December 2019 to February 2020. Data collection methods were carried out by means of observation and questionnaires to farmer groups in Raanan Baru village which consisted of 30 members. In this study of chili farming, and to determine the factors related to the productivity of chili farming, seen from the crosstabulation test using SPSS v25 between each member characteristic (internal factors) and external factors with chili productivity, the descriptive method is used to determine the role of farmer groups on the productivity. Based on the results of research, internal and external factors related to the productivity of chili farming and the role of farmer groups on chili productivity. Factors related to farm productivity of members of the Cita Imbaya farmer group are age, level of education, farming status, intensity of exposure to counseling, and land tenure status. External factors for farmers in the form of business climate and business plan are also related to the productivity of members of the Cita Imbaya farmer group. The role of farmer groups that most members perceive is the role of farmer groups as a vehicle for cooperation and the role of farmer groups as farm production units.
\end{abstract}

Keywords : role; productivity; chilli

\begin{abstract}
ABSTRAK
Penelitian ini bertujuan untuk mengetahui faktor internal dan eksternal yang berkaitan dengan produktivitas usahatani cabai dan mengetahui peran kelompok tani terhadap produktivitas usahatani cabai. Penelitian ini dilakukan pada bulan Desember 2019 sampai bulan February 2020. Dalam penelitian ini metode deskriptif digunakan untuk mengetahui peran kelompok tani terhadap produktivitas usahatani cabai dan untuk mengetahui faktor yang berkaitan dengan produktivitas usahatani cabai di Desa Raanan Baru, dilihat dari hasil uji Crosstabulation dengan menggunakan SPSS v25 antara masing-masing ciri anggota (faktor internal) dan faktor eksternal dengan produktivitas usahatani cabai. Berdasarkan hasil penelitian faktor internal dan eksternal yang berkaitan dengan produktivitas usahatani cabai dan peran kelompok tani terhadap produktivitas usahatani cabai di Desa Raanan Baru. Faktor internal yang memiliki kaitan dengan produkitivitas usahatani anggota Kelompok Tani Cita Imbaya adalah umur, tingkat pendidikan, status berusahatani, intensitas terkena penyuluhan dan status penguasaan lahan. Faktor eksternal petani berupa iklim usaha dan sarana usaha juga memiliki kaitan dengan produkitivitas anggota Kelompok Tani Cita Imbaya. Peran dari Kelompok Tani Cita Imbaya yang paling dirasakan anggota adalah peran kelompok tani sebagai wahana kerjasama dan peran kelompok tani sebagai unit produksi usahatani.
\end{abstract}

Kata Kunci : peran; produktivitas; cabai 


\section{PENDAHULUAN}

\section{Latar Belakang}

Sebagian besar penduduk Indonesia berdomisili di daerah perdesaan dan memiliki mata pencaharian di sektor pertanian. Pertanian juga merupakan kegiatan penunjang kebutuhan pangan masyarakat di dunia. Namun pada kenyataannya, hasil produksi cabai pertanian di pasar semakin langka dan meningkat harga belinya. Meski harga beli komoditas pertanian melambung tinggi, justru setiap tahunnya jumlah petani semakin berkurang. Berdasarkan data Kementrian Pertanian, total produksi cabai pada tahun tahun 2017 sebesar 2,35 juta ton dan terjadi sedikit penurunan pada tahun 2018 sebesar 2,30 juta ton. (Kementrian Pertanian, 2019).

Produksi cabai di Provinsi Sulawesi Utara pada tahun 2014 mengalami peningkatan yaitu 16.972 ton dibandingkan hasil produksi pada tahun 2013 dengan jumlah produksi 16.923 ton. Hal itu dikarenakan lahan yang dimiliki petani dijual atau disewakan, kemudian beralih kerja (Badan Pusat Statistik Sulawesi Utara, 2015).

Petani termasuk pengusaha kecil yang sering dihadapi dengan kondisi yang tidak menguntungkan terutama mengenai masalah harga dan sistem pemasaran. Mereka yang hanya menguasai modal kecil selalu menjadi korban pengusaha yang lebih besar, yang lebih menguasai aset dan sistem pemasaran.

Kesejahteraan petani dan pendapatan merupakan dua hal yang selalu beriringan dan saling terkait satu sama lain. Sehingga dengan adanya peningkatan pendapatan petani berpengaruh pula pada peningkatan kesejahteraan petani. Pendapatan petani dapat ditingkatkan melalui peningkatan produktivitas usahatani dan intensitas tanam yang disertai peningkatan akses petani ke pasar input dan output yang efisien. Peran serta pemerintah dalam upaya meningkatkan produktivitas petani juga dilakukan dengan mengadakan pembangunan dalam sektor pertanian. Pembangunan merupakan sebuah proses multidimensional yang melibatkan perubahan-perubahan besar dalam struktur sosial, sikap mental, dan kelembagaan nasional yang berakselerasi dengan pertumbuhan ekonomi, pemerataan pendapatan, pengurangan pengangguran dan pemberantasan kemiskinan absolut dengan memperhatikan kelestarian lingkungan (Zakaria, 2008).
Program bantuan pemerintah dalam rangka mengadakan pembangunan di sektor pertanian pada umumnya berupa subsidi sarana produksi, bantuan modal langsung, penyuluhan teknologi pertanian, kredit usaha tani, dan sebagainya. Namun, bantuan tersebut belum menghasilkan hasil yang diinginkan. Petani Indonesia masih berpendapatan rendah. Berbagai bantuan yang diberikan juga menyebabkan petani menjadi bergantung dan merasa tidak mampu bergerak sendiri dalam melaksanakan usahataninya. Begitu pula dengan program-program penyuluhan pertanian yang selama ini sudah berjalan, belum mampu secara optimal membantu petani dalam meningkatkan perekonomiannya, serta belum mampu mendorong petani untuk menemukan pemecahan masalahnya sendiri dalam melaksanakan usahataninya (Mushero, 2008).

Hal ini hanya dapat dicapai jika petani mampu berhimpun dalam suatu kekuatan bersama, seperti halnya kelompok tani. Kelompok Tani didefinisikan sebagai sekelompok petani yang secara informal mengkonsolidasikan diri berdasarkan kepentingan bersama dalam berusahatani. Seperti yang dijelaskan dalam peraturan menteri pertanian No. 82/Permentan/OT.140/8/2013, Kelompok Tani yang selanjutnya disebut poktan adalah kumpulan petani/peternak/pekebun yang dibentuk atas dasar 1) kesamaan kepentingan; 2) kesamaan kondisi lingkungan sosial, ekonomi, dan sumberdaya; 3) kesamaan komoditas; serta 4) keakraban untuk meningkatkan dan mengembangkan usaha anggota (Deptan, 2013).

Sedikitnya ada tiga alasan mengapa diperlukan kelompok tani dalam pembangunan pertanian di pedesaan Indonesia. Pertama, rendahnya rasio jumlah PPL (Penyuluh Pertanian Lapangan) dibandingkan dengan jumlah petani sehingga diperlukan wadah yang dapat mempermudah kerja PPL dalam melaksanakan tugas penyuluhan mereka. Kedua, terbatasnya sumberdaya yang dimiliki petani secara individual sehingga dengan bekerjasama dalam kelompok akan mendorong petani untuk menggabungkan sumberdaya mereka menjadi lebih ekonomis. Ketiga, perilaku berkelompok sudah merupakan budaya Indonesia, terutama di pedesaan. 
Keberadaan kelompok tani juga merupakan salah satu potensi yang mempunyai peranan penting dalam membentuk perubahan perilaku anggotanya dan menjalin kemampuan kerjasama anggota kelompoknya. Melalui kelompok tani, proses pelaksanaan kegiatan melibatkan anggota kelompok dalam berbagai kegiatan bersama, akan mampu mengubah atau membentuk wawasan, pengertian, pemikiran minat, tekad dan kemampuan perilaku berinovasi menjadikan sistem pertanian yang maju.

Dari latar belakang di atas, maka peneliti tertarik untuk melakukan penelitian terhadap kelompok tani di Desa Raanan Baru. Penelitian ini bertujuan untuk menjelaskan peran kelompok tani terhadap peningkatan produktivitas usahatani cabai pada kelompok tani di Desa Raanan Baru. Hal di atas yang menjadi latar belakang penulis mengangkat judul penelitian: "Peran Kelompok Tani Terhadap Tingkat Produktivitas Usahatani Benih Cabai di Desa Raanan Baru Kecamatan Motoling Barat.

\section{Rumusan Masalah}

Berdasarkan latar belakang masalah di atas maka penulis menguraikan rumusan masalah di bawah ini :

1. Apa faktor internal dan eksternal yang berkaitan dengan produktivitas usahatani cabai di Desa Raanan Baru?

2. Apakah kelompok tani berperan pada produktivitas cabe di Desa Raanan Baru Kecamatan Motoling Barat Kabupaten Minahasa Selatan?

\section{Tujuan Penelitian}

Berdasarkan pada rumusan masalah di atas, maka penelitian ini bertujuan :

1. Mengetahui faktor internal dan eksternal yang berkaitan dengan produktivitas usahatani cabai di Desa Raanan Baru?

2. Mengetahui peran kelompok tani terhadap peningkatan produktivitas usahatani cabai di Desa Raanan Baru?

Manfaat Penelitian
Manfaat dari penelitian ini yaitu
meningkatkan pengetahuan tentang Peran
Kelompok Tani Cita Imbaya Terhadap
Produktivitas Cabai di Desa Raanan Baru
Kecamatan Motoling Barat Kabupaten Minahasa
Selatan dan diharapkan dapat menjadi bahan studi
bagi peneliti-peneliti selanjutnya dan juga referensi
dalam melaksanakan penelitian.

\section{METODE PENELITIAN}

\section{Waktu dan Tempat Penelitian}

Penelitian ini dilaksanakan sejak bulan Desember 2019 sampai bulan Februari 2020 mulai dari persiapan sampai penyusunan laporan. Tempat penelitian yaitu di Desa Raanan Baru Kecamatan Motoling Barat.

\section{Metode Pengumpulan Data}

Metode pengumpulan data dilakukan secara observasi dan kuesioner pada kelompok tani di Desa Raanan Baru yang terdiri dari 11 anggota. Kelompok tani dipilih sebagai objek penelitian karena eksistensi atau keberadaan kelompok tani yang masih tetap bertahan sampai sekarang sejak dibentuknya kelompok tani ini pada tahun 2006 .

\section{Metode Analisis Data}

1. Untuk mengetahui peran kelompok tani terhadap produktivitas usahatani cabai di desa Raanan Baru, dilihat dengan hasil uji Crosstabulation dengan menggunakan SPSS v25.

2. Untuk mengetahui faktor yang berkaitan dengan produktivitas usahatani cabai di desa Raanan Baru, dilihat dengan hasil uji Crosstabulation dengan menggunakan SPSS v25 antara masing-masing ciri anggota (faktor internal) dan faktor eksternal dengan produktivitas usahatani.

\section{HASIL DAN PEMBAHASAN}

\section{Deskripsi Wilayah Penelitian}

Desa Raanan Baru merupakan salah satu Desa yang terletak di Kecamatan Motoling Barat dengan luas wilayah 1220 ha yang terdiri dari 7 lingkungan. Adapun batas-batas wilayah sebagai berikut :

Sebelah Utara : Desa Toyopon

Sebelah Timur : Desa Motoling

Sebelah Barat : Desa Tondei/Gunung Lolombulan Sebelah Selatan : Perkebunan dan Hutan

\section{Keadaan Penduduk Menurut Jenis Kelamin}

Total keseluruhan jumlah penduduk yang ada di Desa Raanan Baru sebanyak 1.125 jiwa. Tabel 1 menunjukkan jumlah penduduk yang ada di Desa Raanan Baru. 
Tabel 1. Jumlah Penduduk Menurut Jenis Kelamin

\begin{tabular}{cccc}
\hline No. & Jenis Kelamin & $\begin{array}{c}\text { Jumlah Penduduk } \\
\text { (Orang) }\end{array}$ & $\begin{array}{c}\text { Persentase } \\
(\mathbf{\%})\end{array}$ \\
\hline 1. & Laki-laki & 580 & 51,55 \\
2. & Perempuan & 545 & 48,44 \\
\hline & Jumlah & 1125 & 100 \\
\hline
\end{tabular}

Tabel 1 menunjukkan jumlah penduduk berjenis kelamin laki-laki sebanyak 580 jiwa atau $51,55 \%$ dan jumlah penduduk berjenis kelamin perempuan sebanyak 545 jiwa atau $48,44 \%$, yang tersebar dalam 7 (tujuh) lingkungan.

\section{Jumlah Penduduk Menurut Tingkat Pendidikan}

Tingkat pendidikan di Desa Raanan Baru bervariasi mulai dari tamat Sekolah Dasar (SD) sebanyak 255 orang, Sekolah Menengah Pertama (SMP) sebanyak 315 orang, Sekolah Menengah Atas (SMA) sebanyak 405 orang, dan Sarjana sebanyak 150 orang.

Tabel 2. Jumlah Penduduk Berdasarkan Tingkat Pendidikan

\begin{tabular}{cccc}
\hline No. & $\begin{array}{c}\text { Tingkat } \\
\text { Pendidikan }\end{array}$ & $\begin{array}{c}\text { Jumlah } \\
\text { Penduduk } \\
\text { (Orang) }\end{array}$ & Persentase (\%) \\
\hline 1. & Tamat SD & 255 & 22,7 \\
2. & SMP & 315 & 28 \\
3. & SMA & 45 & 36 \\
4. & Sarjana & 150 & 13,3 \\
\hline & Jumlah & 1125 & 100 \\
\hline
\end{tabular}

Sumber: Kantor Kelurahan Raanan Baru

Tabel 2 menunjukkan bahwa yang tamat SD sebanyak 255 orang atau 22,7\%, yang tamat SMP sebanyak 315 orang atau 28\%, tamat SMA sebanyak 405 orang atau $36 \%$, dan Sarjana sebanyak 150 orang $13.3 \%$.

\section{Deskripsi Kelompok Tani Cita Imbaya}

\section{Sejarah Singkat Terbentuknya Kelompok Tani Cita Imbaya}

Kelompok tani Cita Imbaya adalah kelompok tani yang dibentuk sejak tahun 2008, awal dibentuknya kelompok tani ini pada saat mereka sedang melakukan kegiatan mapalus, dan mereka membuat keputusan untuk membentuk satu kelompok tani yang diberi nama Cita Imbaya. Cita Imbaya merupakan bahasa daerah Minahasa lebih khusus bahasa Tontemboan dalam bahasa Indonesia arti dari Cita Imbaya itu sendiri yaitu "kita semua". Dan anggota kelompok tani ini beranggotakan 20 orang dengan struktur organisasi terdiri dari ketua, sekretaris, bendahara dan anggota. Kelompok tani Cita Imbaya yang bertujuan untuk meningkatkan kemampuan yang dimiliki oleh setiap anggotanya ini merupakan kegiatan pembelajaran yang bertujuan agar para anggota mampu mengorganisasikan diri mereka sendiri agar bisa hidup lebih sejahtera.

\section{Karakteristik Responden}

\section{Umur Responden}

Kemampuan bekerja atau melakukan aktifitas secara fisik bahkan cara berpikir seseorang sangat dipengaruhi faktor umur. Demikian juga dengan para petani dalam melakukan pekerjaannya, anggota yang memiliki umur muda tentunya memiliki kondisi fisik yang lebih kuat serta memiliki daya berpikir yang lebih kreatif dibandingkan yang berumur tua. Dari data primer yang diperoleh, usia anggota antara 20 sampai 60 tahun. Komposisi umur responden dalam penelitian ini disajikan pada Tabel 3.

Tabel 3. Distribusi Responden Menurut Umur Anggota Kelompok Tani Cita Imbaya

\begin{tabular}{cccc}
\hline No. & Umur & $\begin{array}{c}\text { Jumlah Penduduk } \\
\text { (Orang) }\end{array}$ & Persentase (\%) \\
\hline 1. & $>60$ & 4 & 13.3 \\
$\mathbf{2 .}$ & $20-29$ & 13 & 43.3 \\
$\mathbf{3 .}$ & $30-40$ & 13 & 43.3 \\
\hline & Jumlah & 30 & 100 \\
\hline
\end{tabular}

Sumber : Wawancara dari Kelompok Tani Cita Imbaya

Tabel 3 menunjukkan bahwa jumlah responden pada umur 20-29 tahun menunjukkan persentase yang sama-sama memiliki 13 responden $43.3 \%$, selanjutnya berada pada usia $>60$ tahun menunjukkan paling sedikit 4 responden $13.3 \%$.

\section{Jumlah Responden Menurut Tingkat Pendidikan}

Peranan pendidikan formal sangat penting dalam usaha peningkatan kualitas seseorang karena berguna dalam pembangunan pribadi serta peningkatan intelektual dan wawasan seseorang. Berdasarkan hasil penelitian, tingkat pendidikan responden tidak bervariasi hanya mulai dari Sekolah Menengah Pertama (SMP) dan Sekolah Menengah Atas (SMA)/sederajat. Komposisi tingkat pendidikan responden dalam penelitian ini dapat dilihat pada Tabel 4.

Tabel 4. Distribusi Responden Menurut Tingkat Pendidikan Anggota Kelompok Tani Cita Imbaya

\begin{tabular}{cccc}
\multicolumn{4}{c}{ Pendidikan Anggota Kelompok Tani Cita Imbaya } \\
No. & Pendidikan & $\begin{array}{c}\text { Jumlah } \\
\text { Responden } \\
\text { (Orang) }\end{array}$ & $\begin{array}{c}\text { Persentase } \\
(\%)\end{array}$ \\
\hline 1. & SD & 4 & 13.3 \\
2. & SMP & 13 & 43.3 \\
3. & SMA/Sarjana & 13 & 43.3 \\
\hline & Jumlah & 30 & 100 \\
\hline
\end{tabular}

Sumber : Wawancara dari Kelompok Tani Cita Imbaya 
Tabel 4 menunjukkan bahwa jumlah responden dengan tingkat pendidikan SMP dan SMA/Sarjana yang sama-sama memiliki 13 responden dengan persentase $43.3 \%$ dan tingkat pendidikan SD yang menunjukkan paling sedikit 4 responden dengan persentase $13.3 \%$.

\section{Status Usahatani}

Status usahatani responden pada penelitian ini dibagi menjadi tiga kategori, yaitu Buruh Tani petani yang tidak memiliki konsentrasi dalam membudidayakan tanaman cabai, pekerjaan sampingan dan pekerjaan utama. Status pekerjaan petani cabai yang memperlihatkan sejauh mana waktu dan perhatian petani terhadap pekerjaannya. Bila petani menjadikan usahatani sebagai mata pencaharian utama, maka seluruh waktu dan perhatiannya akan fokus pada usahatani tersebut. Adapun petani yang menjadikan usahatani sebagai usaha sampingan menyebabkan waktu dan perhatian petani tidak akan fokus maksimal untuk kegiatan pertanian.

Tabel 5. Distribusi Responden Menurut Status Usahatani Anggota Kelompok Tani Cita Imbaya

\begin{tabular}{lccc}
\multicolumn{4}{c}{ Anggota Kelompok Tani Cita Imbaya } \\
\hline No. & Status Usahatani & $\begin{array}{c}\text { Jumlah } \\
\text { Responden } \\
\text { (Orang) }\end{array}$ & $\begin{array}{c}\text { Persentase } \\
(\boldsymbol{\%})\end{array}$ \\
\hline $\mathbf{1 .}$ & Buruh tani & 6 & 20.0 \\
$\mathbf{2 .}$ & Pekerjaan sampingan & 11 & 36.7 \\
$\mathbf{3 .}$ & Pekerjaan utama & 13 & 43.3 \\
\hline \multicolumn{5}{l}{ Sumber: Wawancara dari Kelompok Tani Cita Imbaya }
\end{tabular}

Dapat dilihat dari Tabel 5 bahwa mayoritas responden memiliki pekerjaan utama sebagai petani cabai dengan persentase $43.3 \%$. Hal ini dikarenakan petani mendapat keuntungan dari hasil membudidayakan tanaman cabai sehingga petani dapat memenuhi kebutuhan hidup seharihari.

\section{Pengalaman Berusahatani}

Pengalaman berusahatani diduga mempengaruhi tingkat produksi usahatani dimana semakin lama pengalaman berusahatani maka kemampuan dalam pengelolaan usahatani akan semakin baik. Pada penelitian ini, pengalaman berusahatani anggota kelompok tani tersebar pada kisaran 1-6 tahun. Sehingga peneliti mengkategorikan pengalaman berusahatani anggota kelompok ke dalam tiga kategori yaitu kategori pengalaman berusahatani kurang dari 1 tahun, pengalaman berusahatani 2-3 tahun dan pengalaman berusahatani lebih dari 3 tahun.
Tabel 6. Pengalaman Berusahatani Anggota Kelompok Tani Cita Imbaya

\begin{tabular}{lccc}
\hline No. & $\begin{array}{c}\text { Pengalaman } \\
\text { Berusahatani }\end{array}$ & $\begin{array}{c}\text { Jumlah } \\
\text { Responden } \\
\text { (Orang) }\end{array}$ & $\begin{array}{c}\text { Presentase } \\
(\boldsymbol{\%})\end{array}$ \\
\hline 1. & $<1$ tahun & 6 & 20.0 \\
2. & $2-3$ tahun & 14 & 46.7 \\
3. & $>3$ tahun & 10 & 33.3 \\
\hline \multicolumn{4}{r}{ Sumber : Wawancara dari Kelompok Tani Cita Imbaya }
\end{tabular}

Sumber : Wawancara dari Kelompok Tani Cita Imbaya

Dari Tabel 6 dapat diketahui bahwa mayoritas responden yaitu $46 \%$ atau 14 orang mempunyai pengalaman berusahatani 2-3 tahun, $20 \%$ atau 6 orang kurang dari 1 tahun dalam budidaya pertanian, dan $33.3 \%$ atau 10 orang lebih dari 3 tahun. Hal ini membuktikan bahwa petani responden belum memiliki pengetahuan yang cukup mengenai budidaya cabai.

\section{Intensitas Terkena Penyuluhan}

Kegiatan pembinaan yang pernah diberikan kepada Kelompok Tani Cita Imbaya berupa pelatihan Pengendalian Hama, Metode budidaya cabai, Workshop Manajemen, serta penangkaran benih. Intensitas terkena penyuluhan tertinggi responden adalah sebanyak 5 kali sedangkan intensitas terkena penyuluhan terendah adalah 1 kali, dengan mayoritas responden mengikuti 3 kali penyuluhan. Peneliti mengkategorikan intensitas terkena penyuluhan menjadi tiga kategori, yaitu 1-2 kali mengikuti penyuluhan disebut kategori rendah, 3-4 kali mengikuti penyuluhan disebut kategori sedang, serta 5-6 kali mengikuti penyuluhan disebut kategori tinggi.

Tabel 7. Intensitas Perkena Penyuluhan Kelompok Tani Cita Imbaya

\begin{tabular}{|c|c|c|c|}
\hline No. & $\begin{array}{c}\text { Intensitas Terkena } \\
\text { Penyuluhan }\end{array}$ & $\begin{array}{c}\text { Jumlah } \\
\text { Responden } \\
\text { (Orang) }\end{array}$ & $\begin{array}{c}\text { Persentase } \\
(\%)\end{array}$ \\
\hline 1. & Rendah & 8 & 26.7 \\
\hline 2. & Sedang & 10 & 33.3 \\
\hline \multirow[t]{2}{*}{3.} & Tinggi & 12 & 40.0 \\
\hline & Jumlah & 30 & 100 \\
\hline
\end{tabular}

Sumber : Wawancara dari Kelompok Tani Cita Imbaya

Dari tabel diatas, dapat diketahui bahwa intensitas terkena penyuluhan pada anggota kelompok tani tergolong dalam kategori tinggi. Hal ini dapat dijelaskan pada mayoritas responden mengikuti kegiatan sebanyak 5-6 kali dengan sebaran frekuensi yang menunjukkan persentase sebesar $40.0 \%$ atau 12 orang. 


\section{Luas Lahan}

Lahan terluas yang dimiliki responden adalah 1 ha, sedangkan lahan tersempit yang dimiliki responden adalah $500 \mathrm{~m}^{\wedge} 2$. Lahan merupakan sumber daya utama dalam berusaha tani, sehingga luas lahan sangat mempengaruhi jumlah hasil produksi tanaman hortikultura, untuk melihat luas lahan responden dapat dilihat pada Tabel 8.

Tabel 8. Luas Lahan kelompok tani Cita Imbaya

\begin{tabular}{cccc}
\hline No. & $\begin{array}{c}\text { Luas Lahan } \\
\text { (Ha) }\end{array}$ & $\begin{array}{c}\text { Jumlah Responden } \\
\text { (Orang) }\end{array}$ & $\begin{array}{c}\text { Persentase } \\
(\boldsymbol{\%})\end{array}$ \\
\hline $\mathbf{1}$ & $<0,5$ & 0 & 0 \\
$\mathbf{2}$ & $0,5-1$ & 26 & 88.7 \\
$\mathbf{3}$ & $>1$ & 4 & 13.3 \\
\hline & Jumlah & 30 & 100 \\
\hline
\end{tabular}

Sumber : Diolah dari Data Primer 2020

Dari tabel diatas, dapat diketahui bahwa mayoritas responden mempunyai luas lahan 0,5-1 Ha. Hal ini dapat dijelaskan dengan sebaran frekuensi yang menunjukkan persentase yang besar pada kepemilikan lahan dengan luas 0,5-1 $\mathrm{Ha}$ sebesar $50.0 \%$ atau 15 orang dari total responden.

\section{Status Kepemilikan Lahan}

Lahan yang diusahakan oleh petani responden dalam usahatani cabai oleh kelompok tani Cita Imbaya ini berbeda-beda berdasarkan status kepemilikan lahan. Kepemilikan lahan pada anggota kelompok ini dibedakan menjadi 4 jenis, yaitu : pemilik lahan pribadi dan bagi hasil serta sewa. Penelitian ini membagi status penguasaan lahan menjadi 3 kategori, yaitu status penguasaan lahan sebagai penggarap, sewa lahan dan pemilik lahan. Pemilik lahan merupakan anggota yang benar-benar memiliki lahan, sedangkan bukan pemilik lahan adalah anggota yang bekerja pada lahan orang lain dengan status pekerjaan sebagai penggarap, sewa dan bagi hasil.

Tabel 9. Status Kepemilikan Lahan Anggota Kelompok Tani Cita Imbaya

\begin{tabular}{cccc}
\hline \multicolumn{3}{c}{ Tani Cita Imbaya } \\
No. & $\begin{array}{c}\text { Status } \\
\text { Kepemilikan } \\
\text { Lahan }\end{array}$ & $\begin{array}{c}\text { Jumlah } \\
\text { Responden }\end{array}$ & $\begin{array}{c}\text { Persentase } \\
(\boldsymbol{\%})\end{array}$ \\
\hline 1. & Penggarap & 5 & 16.7 \\
$\mathbf{2 .}$ & Sewa lahan & 12 & 40.0 \\
3. & Pemilik Lahan & 13 & 43.3 \\
\hline & Jumlah & 30 & 100 \\
\hline
\end{tabular}

Sumber : Wawancara dari Kelompok Tani Cita Imbaya

Dari tabel diatas, dapat diketahui bahwa mayoritas status penguasaan lahan responden adalah milik sendiri. Hal ini dapat dijelaskan dengan sebaran frekuensi yang menunjukkan persentase yang besar pada status penguasaan lahan petani pemilik sebesar $43.3 \%$ atau 13 responden.

\section{Peran Kelompok Tani Cita Imbaya}

\section{Wahana Kelas Belajar}

Kelompok tani sebagai wahana belajar dan berorganisasi merupakan suatu wadah bagi setiap anggota kelompok untuk saling berinteraksi guna meningkatkan pengetahuan, keterampilan, dan sikap dalam berusahatani sehingga dapat meningkatkan kemampuan dalam melakukan usahatani.

Tabel 10. Jumlah dan Persentase Responden Menurut Kategori Sebagai Wahana Belajar dan Berorganisasi Tahun 2020

\begin{tabular}{ccc}
\hline Kategori & $\begin{array}{c}\text { Jumlah } \\
\text { Responden }\end{array}$ & $\begin{array}{c}\text { Persentase } \\
(\boldsymbol{\%})\end{array}$ \\
\hline Rendah & - & - \\
Sedang & 18 & 60.0 \\
Tinggi & 12 & 40.0 \\
\hline Jumlah & 30 & 100 \\
\hline Sumber : Wawancara dari Kelompok Tani Cita Imbaya
\end{tabular}

Pada penelitian ini, anggota Kelompok Tani Cita Imbaya menyatakan bahwa peran Kelompok Tani Cita Imbaya sebagai wahana belajar dan berorganisasi digolongkan cukup baik. Hal ini dapat dilihat pada persentase sebesar $60.0 \%$ pada kategori sedang. Sebagai wahana belajar dan berorganisasi, kelompok tani memberikan wadah bagi para penyuluh lapang untuk menyampaikan tambahan informasi dan teknologi terbaru mengenai dunia pertanian kepada para petani. Setiap bulan, kelompok tani ini mengadakan pertemuan dengan penyuluh lapang dari dinas terkait.

\section{Wahana Kerjasama}

Kelompok tani sebagai wahana kerjasama merupakan suatu wadah bagi setiap anggota kelompok untuk memperkuat kerjasama antara sesama petani dalam kelompok dan antara kelompok dan pihak lain untuk menghadapi ancaman, tantangan, hambatan, serta gangguan dalam berusahatani.

\section{Unit Produksi}

Pengkategorian peran kelompok tani sebagai unit produksi usahatani dibagi menjadi 4 kategori, yaitu kategori rendah, sedang, tinggi dan sangat tinggi. Berdasarkan hasil penelitian, anggota Kelompok Tani Cita Imbaya menyatakan bahwa peran Kelompok Tani Cita Imbaya sebagai unit produksi usahatani digolongkan baik.

Tabel 11. Jumlah dan Persentase (\%) Responden Menurut Kategori Sebagai Wahana Kerjasama dan Berorganisasi Tahun 2020

\begin{tabular}{|c|c|c|}
\hline Kategori & $\begin{array}{c}\text { Jumlah } \\
\text { Responden }\end{array}$ & Persentase $(\%)$ \\
\hline Rendah & 1 & 3.3 \\
\hline Sedang & 8 & 26.7 \\
\hline Tinggi & 21 & 70.0 \\
\hline Jumlah & 30 & 100 \\
\hline
\end{tabular}


Pada Tabel 11 dapat diketahui bahwa anggota Kelompok Tani Cita Imbaya menyatakan peran Kelompok Tani Cita Imbaya sebagai wahana kerjasama tergolong kategori baik. Hal itu dapat dilihat dari persentase sebesar $70.0 \%$ berada dalam kategori tinggi.

Tabel 12. Jumlah dan Persentase Responden Menurut Kategori Sebagai Unit Produksi dan Berorganisasi Tahun 2020

\begin{tabular}{ccc} 
& Sebagai Unit Produksi dan Berorganisasi Tahun 2020 \\
\hline Kategori & Jumlah Responden & Persentase (\%) \\
\hline Rendah & - & - \\
Sedang & 11 & 36.7 \\
Tinggi & 19 & 63.3 \\
\hline Jumlah & 30 & 100 \\
\hline
\end{tabular}

Sumber : Wawancara dari Kelompok Tani Cita Imbaya

Dalam perannya sebagai unit produksi usahatani, Cita Imbaya sudah melakukan penyusun rencana usahatani yang dilakukan setiap awal musim tanam. Penyusunan rencana tersebut berupa penggunaan bibit yang akan ditanam, penentuan tanggal tanam, pola tanam yang digunakan serta seluruh kegiatan yang berkaitan dengan teknik budidaya tanaman.

\section{Produktivitas Cabai}

Produktivitas usahatani pada penelitian ini dikaji berdasarkan hasil pertanian petani per satuan lahan yang dimiliki pada saat bergabung dengan kelompok tani. Produktivitas usahatani pada penelitian ini diperoleh berdasarkan data temuan di lapangan. Produktivitas usahatani terendah adalah sebesar $0.02 \%$ dan produktivitas tertinggi adalah $0.30 \%$ dengan rata-rata produktivitas sebesar $0.15 \%$, dan total produktivitas adalah sebagai berikut :

$$
\begin{aligned}
\text { Produktivitas } & =\frac{\text { Total produksi }}{\text { Total Luas lahan }} \times 100 \% \\
\text { Produktivitas } & =\frac{3555 \mathrm{~kg}}{53000 \mathrm{~m}^{2}} \times 100 \% \\
& =0.07 \%
\end{aligned}
$$

Oleh sebab itu, pengkategorian produktivitas ini dibagi menjadi 3 kategori, yaitu produktivitas $<0,10 \%$ (rendah), $\quad 0,20-0,29 \%$ (sedang), dan $>0,30 \%$ (tinggi).

Tabel 13. Jumlah dan Persentase Produktivitas Usahatani Anggota Kelompok Tani Cita Imbaya Berdasarkan Penurunan dan Peningkatan Produktivitas Tahun 2020

\begin{tabular}{ccc}
\hline Kategori & Jumlah Responden & Persentase (\%) \\
\hline$<0,10 \%$ & 11 & 36.7 \\
$0,20-0,29 \%$ & 16 & 53.3 \\
$>0,30 \%$ & 3 & 10.0 \\
\hline Jumlah & 30 & 100 \\
\hline Sumber $\cdot$ Wawancara Kelompok Tani Cita Imbaya Tahun 2020
\end{tabular}

Dapat dilihat pada tabel di atas bahwa produktivitas usaha tani anggota Kelompok Tani Cita Imbaya terbagi menjadi 3 kategori. Anggota kelompok tani peningkatan peling tinggi hanya 3 orang dengan persentase sebesar $10.0 \%$. Sedangkan sebanyak 16 orang atau $53.3 \%$ anggota Kelompok Tani Cita Imbaya mengalami peningkatan produktivitas usahatani cukup tinggi setelah bergabung dengan kelompok tani.

\section{Faktor Internal dan Eksternal \\ Kelompok Tani dengan Produktivitas}

Faktor internal petani yang akan dijelaskan meliputi umur, pendidikan, status usahatani, pengalaman berusahatani, intensitas terkena penyuluhan, serta status penguasaan dan luas lahan dari 11 responden tersebut. Sedangkan faktor eksternal petani yang akan dijelaskan yaitu sarana usaha dan iklim usaha dari budidaya padi di Desa Raanan Baru, Kecamatan Mitoling Barat, Kabupaten Minahasa Selatan.

\section{Faktor Internal}

\section{Umur}

Peneliti menggolongkan umur responden berdasarkan rentang atau siklus lamanya hidup manusia. Pengkategorian umur pada penelitian ini didasarkan dari selang umur produktif yaitu $<60$ tahun serta non produktif pada umur $<15$ tahun dan $>64$ tahun (Rusli 2005). Umur terendah responden pada penelitian ini adalah 20 tahun, sedangkan umur tertinggi adalah 80 tahun. Dengan rata-rata umur responden adalah 53 tahun.

Tabel 14. Jumlah dan Persentase Kategori Umur Anggota dengan Produktivitas Usahatani Di Kelompok Tani Cita Imbaya Tahun 2020

\begin{tabular}{cccccccccc}
\hline \multirow{2}{*}{ No Kategori } & \multicolumn{7}{c}{ Produktivitas } & \multirow{2}{*}{ Total } & \multirow{2}{*}{$\%$} \\
\cline { 2 - 9 } & & Rendah & $\%$ & Sedang & $\%$ & Tinggi & \% & & \\
\hline 1 & $>60$ & 2 & 18.2 & 1 & 6,3 & 1 & 33,4 & 4 & 13,4 \\
2 & $30-40$ & 5 & 45,5 & 7 & 43, & 1 & 33,3 & 13 & 43,3 \\
3 & $20-29$ & 4 & 36.3 & 8 & 50. & 1 & 33,3 & 13 & 43,3 \\
& & & & & 0 & & & & \\
\hline \multicolumn{2}{l}{ Total } & 11 & 100 & 16 & 100 & 3 & 100 & 30 & 100 \\
\hline
\end{tabular}

Sumber : Hasil Uji Crosstabulation, SPSS 25

Berdasarkan tabel diatas, diketahui bahwa sebesar 43.3 persen atau 13 responden berada pada kategori sedang dan tinggi yaitu 20-29 dan 30-40 tahun dan 13.4 persen atau 4 responden berada pada kategori non produktif yaitu $>63$ tahun. Jika dilihat dari kategori produktivitas usahatani anggota dengan kategori umur tersebut, dapat dilihat bahwa kategori umur produktif mayoritas berada pada kategori produktivitas meningkat sebesar 50.0 persen atau 8 orang serta hanya 6.3 persen atau 1 orang yang mengalami produktivitas rendah dalam kategori sedang. 


\section{Tingkat Pendidikan}

Pada penelitian ini, pendidikan tertinggi responden adalah tamat SMA, sedangkan pendidikan terendah adalah tidak sekolah, dengan mayoritas responden adalah tidak sekolah.

\begin{tabular}{|c|c|c|c|c|c|c|c|c|c|}
\hline \multirow{3}{*}{ No } & \multirow{3}{*}{$\begin{array}{rr}\text { el } & \text { 15. } \\
& \mathbf{P} \\
2 \\
\text { Kategori }\end{array}$} & $\begin{array}{l}\text { Jumlah dan } \\
\text { Produktivitas } \\
2020 \\
\end{array}$ & \multicolumn{2}{|c|}{$\begin{array}{l}\text { Persentase T } \\
\text { Usahatani di }\end{array}$} & $\begin{array}{l}\text { ingkat I } \\
\text { Kelomp }\end{array}$ & \multicolumn{2}{|c|}{$\begin{array}{l}\text { Pendidikan A } \\
\text { ok Tani Cita }\end{array}$} & $\begin{array}{l}\text { Inggota } \\
\text { Imbaya }\end{array}$ & $\begin{array}{l}\text { dengan } \\
\text { Tahun }\end{array}$ \\
\hline & & \multicolumn{6}{|c|}{ Produktivitas } & \multirow[b]{2}{*}{ Total } & \multirow{2}{*}{$\%$} \\
\hline & & Rendah & $\%$ & Sedang & $\%$ & Tinggi & $\%$ & & \\
\hline 1 & SD & 2 & 18,2 & 2 & 12,5 & 0 & 0 & 4 & 13,4 \\
\hline 2 & SMP & 6 & 54,5 & 6 & 37,5 & 1 & 33,4 & 13 & 43,3 \\
\hline \multirow[t]{2}{*}{3} & $\begin{array}{l}\text { SMA- } \\
\text { Sarjana }\end{array}$ & 3 & 27,3 & 8 & 50 & 2 & 66,6 & 13 & 43,3 \\
\hline & Total & 11 & 100 & 16 & 100 & 3 & 100 & 30 & $\frac{100}{100}$ \\
\hline
\end{tabular}

Berdasarkan tabel diatas, dapat diketahui bahwa walaupun petani dengan tingkat pendidikan SMP dan SMA/Sarjana sama-sama memiliki persentase produktivitas usahatani cukup baik yaitu berada pada kategori meningkat dengan persentase sebesar 43.3 persen. Berbeda halnya dengan anggota kelompok yang memiliki pendidikan rendah yaitu SD, hanya 4 orang dari 2 orang anggota yang meningkat produktivitasnya. Dengan kata lain, tingkat pendidikan anggota kelompok tani tidak memiliki kaitan dengan produktivitas usahatani anggota.

\section{Status Berusahatani}

Responden dalam penelitian ini adalah petani yang menjadikan usahatani sebagai buruh tani, pekerjaan utama dan sebagai pekerjaan sampingan. Responden menjadikan usahatani sebagai pekerjaan sampingan dikarenakan pendapatan yang didapatkan dari bertani kurang mencukupi kebutuhan. Sedangkan responden yang menjadikan usahatani sebagai pekerjaan utama dikarenakan tidak memiliki pekerjaan lain selain bertani.

Tabel 16. Jumlah dan Persentase Antara Status Berusahatani Anggota dengan
Produktivitas Usahatani di Kelompok Tani Cita Imbaya Tahun 2020

Oleh karena itu, jumlah dan persentase data yang paling dominan dari Tabel 16 menunjukkan bahwa anggota dengan status berusahatani sebagai pekerjaan utama mengalami peningkatan produktivitas sebesar 43.9 persen. Persentase anggota kelompok tani yang menjadikan usahatani sebagai pekerjaan utama mengalami peningkatan produktivitas dalam kategori tinggi sebesar 66.6 persen.

\section{Pengalaman Berusahatani}

Pengalaman berusahatani diduga mempengaruhi tingkat produksi usahatani dimana semakin lama pengalaman berusahatani petani maka kemampuan dalam pengelolaan usahatani akan semakin baik. Pada penelitian ini, pengalaman berusahatani anggota kelompok tani tersebar pada kisaran 2-6 tahun. Sehingga peneliti mengkategorikan pengalaman berusahatani anggota kelompok kedalam dua kategori yaitu kategori pengalaman berusahatani kurang dari 1 tahun, 2-3 tahun, dan pengalaman berusahatani lebih dari 3 tahun.

\begin{tabular}{|c|c|c|c|c|c|c|c|c|c|}
\hline \multirow{2}{*}{ No } & \multirow{2}{*}{ Kategori } & \multicolumn{6}{|c|}{ Produktivitas } & \multirow{2}{*}{ Total } & \multirow{2}{*}{$\%$} \\
\hline & & Rendah & $\%$ & Sedang & $\%$ & Tinggi & $\%$ & & \\
\hline 1. & $<1$ Tahun & 2 & 18,1 & 2 & 12,5 & 2 & 66,6 & 6 & 20 \\
\hline 2. & 2-3 Tahun & 4 & 36,3 & 9 & 56,3 & 1 & 33,3 & 14 & 46,6 \\
\hline \multirow[t]{2}{*}{3.} & $>3$ Tahun & 5 & 45,4 & 5 & 31,2 & 0 & 0 & 10 & 33,4 \\
\hline & Total & 11 & 100 & 16 & 100 & 3 & 100 & 30 & 100 \\
\hline
\end{tabular}

Sumber: Hasil Uji Crosstabulation, SPSS 16.0

Dari tabel diatas, dapat diketahui bahwa pengalaman berusahatani anggota kelompok mayoritas berada pada pengalaman berusahatani 2-3 tahun dengan persentase 46.6 persen. Sedangkan anggota yang memiliki pengalaman berusahatani kurang dari 1 tahun memiliki persentase sebesar 66.6 persen dengan 2 responden. Berdasarkan tabel tabulasi silang tersebut dapat dikatakan bahwa lamanya pengalaman berusahatani anggota memiliki kaitan dengan produktivitas usahatani. Petani yang memiliki pengalaman 2-3 tahun, memiliki pengetahuan berusahatani lebih banyak daripada petani yang baru sehingga produksi petani yang berpengalaman lebih tinggi.

\section{Intensitas Terkena Penyuluhan}

Kegiatan penyuluhan yang pernah diberikan kepada Kelompok Tani Cita Imaya berjumlah 4 pelatihan yaitu Pengendalian Hama, Iklim, Teknik budidaya cabai hibrida, serta penangkaran benih. Intensitas terkena penyuluhan tertinggi responden adalah sebanyak 5 kali sedangkan intesitas terkena penyuluhan terendah adalah 1 kali, dengan mayoritas responden mengikuti 3 kali penyuluhan. Peneliti mengkategorikan intensitas terkena penyuluhan menjadi tiga kategori, yaitu 1-2 kali mengikuti penyuluhan disebut kategori rendah, 3-4 kali mengikuti penyuluhan disebut kategori sedang, serta $>5$ kali mengikuti penyuluhan disebut kategori tinggi.

\begin{tabular}{|c|c|c|c|c|c|c|c|c|c|}
\hline \multirow{2}{*}{ No } & \multirow{2}{*}{ Kategori } & \multicolumn{6}{|c|}{ Produktivitas } & \multirow{2}{*}{ Total } & \multirow[b]{2}{*}{$\%$} \\
\hline & & Rendah & $\%$ & Sedang & $\%$ & Tinggi & $\%$ & & \\
\hline 1. & $1-2$ & 2 & 18,1 & 5 & 31,3 & 1 & 33,3 & 8 & 26,7 \\
\hline 2. & $3-4$ & 5 & 45,4 & 4 & 25 & 1 & 33,3 & 10 & 33,3 \\
\hline 3. & $>5$ & 4 & 36,3 & 7 & 43,7 & 1 & 33,4 & 12 & 40.0 \\
\hline & Total & 11 & 100 & 16 & 100 & 3 & 100 & 30 & 100 \\
\hline
\end{tabular}


Dari tabel diatas, dapat diketahui bahwa mayoritas intensitas terkena penyuluhan anggota berada pada kategori tinggi dengan tingkat produktivitas usahatani yang mengalami peningkatan menunjukkan persentase yang dominan sebesar 40.0 persen. Berdasarkan hasil tersebut dapat dikatakan bahwa intensitas terkena penyuluhan pada anggota kelompok memiliki kaitan dengan produktivitas usahatani anggota.

\section{Luas Lahan}

Luas lahan merupakan media yang digunakan oleh petani untuk menjalankan usaha pertaniannya dan diukur dengan satuan hektar (Muhyidin 2010). Lahan terluas yang dimiliki responden adalah 1 ha, sedangkan lahan tersempit yang dimiliki responden adalah $500 \mathrm{~m} 2$, dengan rata-rata luas lahan sebesar $3048.33 \mathrm{~m} 2$.

\begin{tabular}{|c|c|c|c|c|c|c|c|c|c|}
\hline \multirow{2}{*}{ No } & \multirow{2}{*}{ Kategori } & \multicolumn{6}{|c|}{ Produktivitas } & \multirow{2}{*}{ Total } & \multirow{2}{*}{$\%$} \\
\hline & & Rendah & $\%$ & Sedang & $\%$ & Tinggi & $\%$ & & \\
\hline 1. & $<0,5 \mathrm{Ha}$ & 0 & 0 & 0 & 0 & 0 & 0 & 0 & 0 \\
\hline 2. & $0,5-1 \mathrm{Ha}$ & 7 & 63.6 & 16 & 100 & 3 & 100 & 26 & 88.7 \\
\hline 3. & $>1 \mathrm{Ha}$ & 4 & 36.4 & 0 & 0 & 0 & 0 & 4 & 13.3 \\
\hline & Total & 11 & 100 & 16 & 100 & 3 & 100 & 30 & 100 \\
\hline
\end{tabular}

Dari tabel diatas, dapat diketahui bahwa persentase luas lahan 0.5-1 ha menunjukkan persentase dominan sebesar 100 persen dalam kategori sedang dan tinggi pada kolom produktivitas usahatani yang mengalami peningkatan. Sedangkan, anggota dengan luas lahan $>1$ ha memiliki persentase 13.3 persen.

\section{Status Penguasaan Lahan}

Pada penelitian ini, status penguasaan lahan dibagi menjadi 3 kategori, yaitu petani penggarap pemilik lahan dan sewa lahan. Pemilik lahan merupakan anggota yang benar-benar memiliki lahan, sedangkan bukan pemilik lahan adalah anggota yang bekerja pada lahan orang lain dengan status pekerjaan sebagai pemetik, bagi hasil dan sewa. Mayoritas anggota dari kelompok tani Cita Imbaya memiliki status penguasaan lahan pemilik.

\section{Faktor Eksternal}

\section{Iklim Usaha}

Pengambilan keputusan usahatani dari berbagai alternatif pilihan yang ada, individu selalu dihadapkan pada suatu kondisi iklim usaha dalam mengambil keputusan tersebut. Oleh karena itu, iklim usaha yang kondusif dapat menumbuhkan minat petani untuk meningkatkan usahataninya.

\begin{tabular}{|c|c|c|c|c|c|c|c|c|c|}
\hline \multirow{2}{*}{ No } & \multirow{2}{*}{ Kategori } & \multicolumn{6}{|c|}{ Produktivitas } & \multirow{2}{*}{ Total } & \multirow{2}{*}{$\%$} \\
\hline & & Rendah & $\%$ & Sedang & $\%$ & Tinggi & $\%$ & & \\
\hline 1. & Rendah & 1 & 9,1 & 3 & 18,7 & 0 & & 4 & 13,4 \\
\hline 2. & Sedang & 9 & 81,8 & 12 & 75.0 & 2 & 66,6 & 23 & 76,6 \\
\hline \multirow[t]{2}{*}{3.} & Tinggi & 1 & 9,1 & 1 & 6,3 & 1 & 33,3 & 3 & 10 \\
\hline & Total & 11 & 100 & 16 & 100 & 3 & 100 & 30 & 100 \\
\hline
\end{tabular}

Berdasarkan tabel diatas, diketahui bahwa sarana usahatani paling dominan dikategorikan sedang sebesar 76.6 persen dari 23 responden dengan peningkatan produktivitas usahatani pada kategori rendah sebesar 81.8 persen dari 9 responden. Pada dasarnya, keseluruhan anggota sudah merasakan berbagai kemudahan dalam mengakses informasi teknologi yang selalu diperbaharui, serta teknik-teknik budidaya guna meningkatkan produktivitas.

\section{Peran Kelompok Tani Terhadap Peningkatan Produktivitas Usahatani Cabai di Desa Raanan Baru}

\section{Hubungan Peran Kelompok Tani Sebagai Wahana dengan Produktivitas}

Hubungan Peran Kelompok Tani Sebagai Wahana Belajar dan Berorganisasi dengan Produktivitas Cabai Kelompok Tani Cita Imbaya dalam menjalankan perannya sebagai wahana belajar dan berorganisasi memberikan fasilitas berupa bimbingan, pelatihan dan penyuluhan kepada anggota secara kontinyu. Kegiatan bimbingan dan pelatihan ini biasanya mengenai budidaya dan pengelolaan usahatani yang baik, produktif, dan menghasilkan panen yang lebih baik. Kegiatan bimbingan dan pelatihan dilakukan setiap bulan tepatnya pada hari jumat di minggu pertama mulai dari pukul 07.00 WIB hingga pukul 11.00 WIB oleh penyuluh lapang.

Tabel 23. Jumlah dan Persentase Peran Kelompok Tani Cita Imbaya Sebagai
\begin{tabular}{cccccccccc} 
Wahana Belajar dengan Produktivitas Usahatani Anggota \\
\hline \multirow{2}{*}{ No } & \multirow{2}{*}{ Kategori } & \multicolumn{7}{c}{ Produktivitas } \\
\cline { 2 - 9 } & Rendah & $\%$ & Sedang & \% & Tinggi & $\%$ & Total & $\%$ \\
\hline 1. & Rendah & 0 & 0 & 0 & 0 & 0 & 0 & 0 & 0 \\
2. & Sedang & 6 & 54,5 & 10 & 62,5 & 2 & 66,6 & 18 & 60 \\
3. & Tinggi & 5 & 45,4 & 6 & 37,5 & 1 & 33,3 & 12 & 40 \\
\hline & Total & 11 & 100 & 16 & 100 & 3 & 100 & 30 & 100 \\
\hline Sumber: SPSS 25 & & & & & & & &
\end{tabular}

Tabel 23 memperlihatkan bahwa peran kelompok tani sebagai wahana belajar dan berorganisasi dikategorikan sedang, jumlah dan persentase responden yang menyatakan hal tersebut dengan produktivitas yang tinggi yaitu $66.6 \%$ dengan mayoritas $60 \%$ responden yang berada pada kondisi produktivitas yang mengalami peningkatan.

\section{Hubungan Peran Kelompok Tani Sebagai Wahana Kerja Sama dengan Produktivitas Cabai}

Kelompok tani sebagai wahana kerjasama merupakan tempat untuk memperkuat kerjasama baik di antara sesama petani dalam kelompok tani dan antara kelompok tani maupun dengan pihak lain. Melalui kerjasama ini diharapkan usahatani lebih efisien dan lebih mampu menghadapi ancaman, tantangan, hambatan, gangguan serta lebih menguntungkan anggota.

\begin{tabular}{|c|c|c|c|c|c|c|c|c|c|}
\hline \multirow[b]{2}{*}{ No } & \multirow[b]{2}{*}{ Kategori } & \multicolumn{6}{|c|}{ Produktivitas } & \multirow[b]{2}{*}{ Total } & \multirow[b]{2}{*}{$\%$} \\
\hline & & Rendah & $\%$ & Sedang & $\%$ & Tinggi & $\%$ & & \\
\hline 1. & Rendah & 1 & 9.1 & 0 & 0 & 0 & & 1 & 3,3 \\
\hline 2. & Sedang & 2 & 18,1 & 5 & 31,2 & 1 & 33,3 & 8 & 26,6 \\
\hline 3. & Tinggi & 8 & 72,7 & 11 & 68,8 & 2 & 66,6 & 21 & 70.0 \\
\hline & Total & 11 & 100 & 16 & 100 & 3 & 100 & 30 & 100 \\
\hline
\end{tabular}

Agrisosioekonomi : Jurnal Transdisiplin Pertanian (Budidaya Tanaman, Perkebunan, Kehutanan, Peternakan, Perikanan Ekonomi dan Teknologi Pangan serta Teknologi Pertanian). 
Tabel 24 menunjukkan persentase responden yang menyatakan bahwa peran kelompok tani sebagai wahana kerjasama dinyatakan sangat baik responden yang menyatakan hal tersebut yaitu sebesar $70.0 \%$ dengan 21 responden. Pada tabel tersebut juga dapat dilihat bahwa semakin tinggi peran kelompok tani sebagai wahana kerjasama, maka produktivitas usahatani anggota juga meningkat cukup tinggi.

\section{Unit Produksi}

Kelompok tani sebagai unit produksi usahatani merupakan satu kesatuan usaha yang terdiri dari unit penyedia sarana dan prasarana produksi, unit pengolahan serta pemasaran. Penelitian ini menggunakan alat analisis korelasi Chi-Square untuk melihat hubungan dari peran kelompok tani sebagai unit produksi usahatani terhadap roduktivitas usahatani di Cita Imbaya.

\begin{tabular}{|c|c|c|c|c|c|c|c|c|c|}
\hline \multirow[b]{2}{*}{ No } & \multirow[b]{2}{*}{ Kategori } & \multicolumn{6}{|c|}{ Produktivitas } & \multirow[b]{2}{*}{ Total } & \multirow[b]{2}{*}{$\%$} \\
\hline & & Rendah & $\%$ & Sedang & $\%$ & Tinggi & $\%$ & & \\
\hline 1 & Rendah & 0 & 0 & 0 & 0 & 0 & 0 & 0 & 0 \\
\hline 2 & Sedang & 3 & 27,2 & 7 & 43,75 & 1 & 33,3 & 11 & 36,6 \\
\hline 3 & Tinggi & 8 & 72,7 & 9 & 56,25 & 2 & 66.6 & 19 & 63,3 \\
\hline & Total & 11 & 100 & 16 & 100 & 3 & 100 & 30 & 100 \\
\hline
\end{tabular}

Tabel 25 menunjukkan persentase responden yang menyatakan bahwa peran kelompok tani sebagai unit produksi dinyatakan sangat baik, responden yang menyatakan hal tersebut yaitu sebesar 63,3\%. Namun pada tabel tersebut juga dapat dilihat bahwa semakin tinggi peran kelompok tani sebagai unit produksi, maka produktivitas usahatani anggota juga memilki peningkatan yang rendah. Hal itu dapat dibuktikan dengan persentase sebesar $72.7 \%$ peran kelompok tani sebagai unit produksi dengan produktivitas usahatani anggotanya meningkat.

\section{KESIMPULAN DAN SARAN}

\section{Kesimpulan}

1. Faktor internal yang memiliki kaitan dengan produkitivitas usahatani anggota Kelompok Tani Cita Imbaya adalah umur, tingkat pendidikan, status berusahatani, intensitas terkena penyuluhan dan status penguasaan lahan. Faktor eksternal petani berupa iklim usaha dan sarana usaha juga memiliki kaitan dengan produkitivitas anggota Kelompok Tani Cita Imbaya.

2. Peran dari Kelompok Tani Cita Imbaya yang paling dirasakan anggota adalah peran kelompok tani sebagai kelas belajar dan peran kelompok tani

\section{Saran}

Berdasarkan hasil penelitian dapat

dikemukakan beberapa saran yaitu sebagai berikut:

1. Bagi anggota Kelompok Tani Cita Imbaya, disarankan dapat mempertahankan keberadaan kelompok tani dan lebih aktif lagi dalam mengikuti kegiatan kelompok tani sehingga kelompok tani ini bisa terus berdiri dan bisa membantu petani anggota mencapai keberhasilan bersama.

2. Penelitian ini telah menjelaskan bahwa Kelompok Tani Cita Imbaya telah menjalankan perannya sebagai kelompok tani yang baik bagi anggotanya sehingga patut dijadikan percontohan bagi kelompok tani lainnya agar bisa mempertahankan sikap bekerjasama dan teratur sehingga produktivitas usahatani juga turut meningkat. Namun, pengurus kelompok perlu untuk lebih menjangkau anggota kelompok tani sehingga bisa meraih keberhasilan bersama dan merata.

\section{DAFTAR PUSTAKA}

Badan Pusat Statistik, 2015. Produksi Cabai Besar, Cabai Rawit, Dan Bawang Merah. [internet]. [Diakses Pada Tanggal 5 Februari 2020]. Dapat di unduh dari: https://www.bps.go.id/pressrelease/2015/ 08/03/1168/produksi-cabai-besar-1-075juta-ton-cabai-rawit-0-8-juta-ton-danbawang-merah-1-234-juta-ton.html

Departemen pertanian, (2013). Peraturan mentri pertanian No.82/Permentan /OT.140/8/2013. Kementrian Pertanian.

Materi Penyuluhan Pertanian. Penguatan Kelembagaan Petani Buku III Kelompok Tani Sebagai Unit Produksi. Pusat Penyuluhan Pertanian. Badan Penyuluhan Dan Pengembangan SDM Pertanian. Kementrian Pertanian.Tahun 2012.

Mushero, Heroni. 2008. Pemberdayaan Petani Melalui Gabungan Kelompok Tani (GAPOKTAN) .http://heronimushero. wordpress.com /2008/03/05/pe berdayaan- petani- melalui- gabungankelompok- tani- gapoktan/. Diakses pada tanggal 19 November 2019.

Zakaria. 2008. Kemunduran Mutu Ikan Gurami (Osphornemus gouramy)Pasca Panen pada Penyimpanan Suhu Chilling. IPB. 